\title{
THE GENESIS OF ULTRAMAFIC LAMPROPHYRES
}

\author{
Stephen F. Foley ${ }^{1}$ and Alexandre V. Andronikov ${ }^{2}$ \\ ${ }^{1}$ University of Greifswald, Germany; ${ }^{2}$ University of Michigan, U.S.A.
}

\section{ULTRAMAFIC LAMPROPHYRE TYPES AND THEIR CLASSIFICATION}

The ultramafic lamprophyres form a heterogeneous group of alkaline rocks whose origin has never been adequately explained. They are generally attributed to melting of carbonate-bearing peridotites, but details are lacking as to how and why the parental melts for various ultramafic lamprophyres differ. The commonest ultramafic lamprophyres are alnöites (melilitedominated) and aillikites (carbonate-dominated). In his review of lamprophyres, Rock (1991) concluded these two groups are derived from distinct types of primary mantle-derived melts. The nomenclature of these rocks is confused and has often changed: recent IUGS recommendations have tried to solve this by dismantling the lamprophyre construct, assigning alnöites to the melilitites and aillikites to the silicocarbonatites. From a petrogenetic point of view, this would appear to confirm them being derived from two distinct primary magma types.

In recent years, diamonds have been discovered in ultramafic lamprophyres in northeastern Canada and Greenland, indicating that conventional models for the genesis of these rocks, which place their origin shallower than $120 \mathrm{~km}$, must be in error. Competing hypotheses explain ultramafic lamprophyres as (1) primary melts of carbonated peridotite, (2) partial melts of peridotite that has been previously uniformly metasomatized by carbonatitic melts, and (3) partial melts of heterogenous mantle consisting of carbonatebearing veins in peridotite.

\section{EXPERIMENTAL CONSTRAINTS ON ULTRAMAFIC LAMPROPHYRE MELT GENESIS}

There are two main approaches to experimental studies which Wyllie (1987) named the forward and inverse approaches. The forward method investigates the partial melting behaviour of peridotite, the presumed source rock, with various amounts of added volatile components. The inverse method investigates the liquidus minerals of the rock in question, here ultramafic lamprophyre, and attempts to find conditions of pressure, temperature, $\mathrm{fO}_{2}$ and volatile mixtures that permit stabilization of all the peridotite minerals together at the liquidus. If successful, results from these two approaches will agree about all conditions of origin of the melt.

However, this interpolation has been shown to be problematic for alkaline and volatile-rich rocks because of the large number of varaibles and the nearimpossibility of identifying the liquid compositions exactly in near-solidus experiments on peridotite. A large number of experiments on peridotite with mixed volatiles were conducted in the late 1970s and early 1980s (e.g. Wyllie 1978; Eggler 1978; Olafsson and Eggler, 1983) but these have only been able to give general pointers as to the type of melts produced, and cannot distinguish in any detail between melts such as kimberlites, melilitites, carbonatites and the different types of ultramafic lamprophyres. This is particularly true for melts that apparently straddle the gap between silicic and carbonatitic melts. Recent experiments at higher pressures have shown that near-solidus melts of carbonated peridotite can produce melts broadly resembling ultramafic lamprophyres and kimberlites at pressures of 5-6 GPa (Ryabchikov et al., 1993; Dalton and Presnall, 1998), but that these are at extremely low degrees of melting $(<2 \%)$.

We have conducted high pressure experiments on alnöitic ultramafic lamprophyres from Beaver Lake, eastern Antarctica (Andronikov and Egorov, 1993; Foley et al., 2002), to attempt to constrain the source mineralogy of the rocks. These are, to our knowledge, the first liquidus experiments on an ultramafic lamprophyres composition, and they show that olivine and clinopyroxene are the liquidus minerals at low pressures $(<2.5 \mathrm{GPa})$. Hydrous phases do not occur within $150^{\circ} \mathrm{C}$ of the liquidus, and carbonates occur only at even lower temperatures. Together with the absence of orthopyroxene in all experiments, including subsolidus, this does not favour an origin as primary melts of carbonated peridotite, but does not distinguish between the other two hypotheses mentioned above. 


\section{THE ORIGIN OF ULTRAMAFIC LAMPROPHYRES IN RIFTED ARCHEAN CRATONS}

However, $\mathrm{Sr}$ and $\mathrm{Nd}$ isotopic results on the Beaver lake rocks clearly favour the existence of phlogopite- and carbonate-bearing veins in the source region. These veins were formed by solidification of low-degree melts which were themselves formed at depths of $130-160 \mathrm{~km}$ by perturbation of an initially very cold cratonic geotherm during the early stages of development of a rift (Figure 1). The veins are reactivated by further upward and outward movement of the lithosphereasthenosphere boundary after a period of tens to hundreds of millions of years. In this model, both alnöites and aillikites are the hybrids of melts of peridotites and rift-related veins. It is the character of the initial melts at $130-160 \mathrm{~km}$ depth in oxidising conditions that lead to the veins that are the key to the difference between ultramafic lamprophyres and other types of alkaline melts.

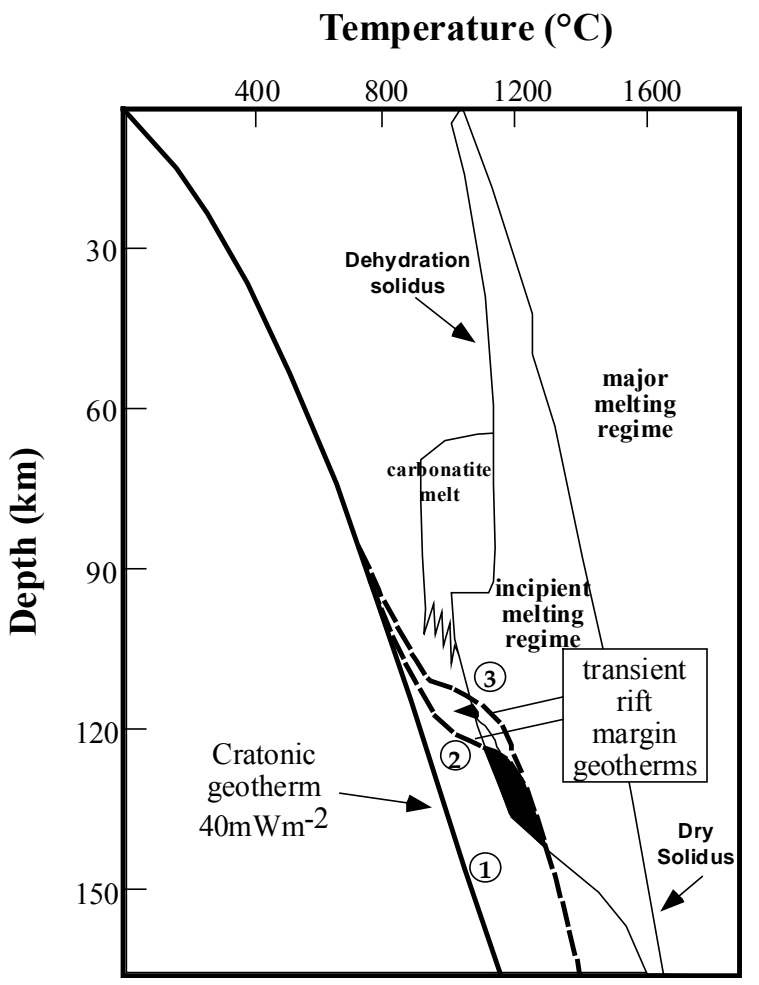

Figure 1: Origin of ultramafic lamprophyres of Beaver Lake in the developing rift. Stage 1 is the original cratonic geotherm before the initiation of the LambertAmery rift. Stage 2 indicates perturbation of this geotherm, causing incipient melting at depths greater than $130 \mathrm{~km}$ where melts are carbonate-rich. These reactive melts cannot proceed far, but solidify as veins rich in phlogopite and carbonate within the overlying lithosphere. Later further upward and outward movement of the lithosphere-asthenosphere boundary re-melts these veins, producing the ultramafic lamprophyre parental magma at stage 3. Modified after Foley et al. (2002).

\section{ONE OR TWO TYPES OF ULTRAMAFIC LAMPROPHYRE MAGMA?}

Petrographic, mineral chemical and whole-rock geochemical data from ultramafic lamprophyres belonging to the alnöite (Beaver Lake) and aillikite (Aillik Bay in Labrador) groups indicate that they have broadly similar characteristics and that both are probably related in origin to melilitites.

Furthermore, the occurrence of parts of a single aillikite dyke at Aillik Bay that would be classified as melilitolite and silicocarbonatite if they occurred separately (Figure 2) indicates that classification systems alone cannot be used to deduce parental magma groups. The division between the alnöites and aillikites is synthetic and semantic in origin. A continuum exists between ultramafic lamprophyres, kimberlites and melilitites which can be explained by this type of genetic model.

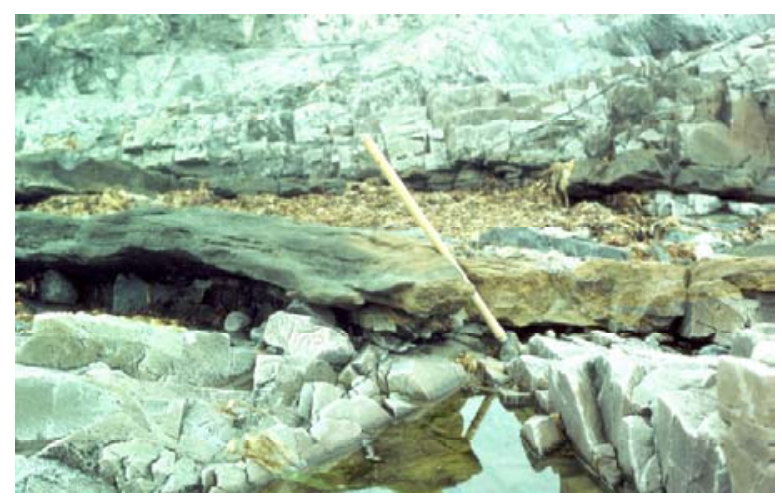

Figure 2: Aillikite dyke at Aillik Bay, Labrador, showing a "carbonatization front" slightly left of the hammer. A sample of the dark-coloured aillikite at the left would classify as belonging to the melilitolite group, whereas a sample of the carbonate-rich yellow aillikite (right) would be assigned to the silicocarbonatites. Although these rocks are clearly related in this case, the occurrence of similar rocks as discrete dykes could lead to the assumption that they are derived from entirely unrelated parental magmas. 


\section{REFERENCES}

Andronikov A.V., Egorov L.S., 1993. Mesozoic alkalineultramafic magmatism of Jetty Peninsula. In: Findlay R.H., Unrug R, Banks M.R., Veevers J.J. (Eds.), Gondwana Eight: assembly, evolution and dispersal. Balkema, Rotterdam Brookfield, pp. 547-557.

Dalton J.A., Presnall D.C., 1998. The continuum of primary carbonatitic-kinberlitic melt compositions in equilibrium with lherzolite: data from the system $\mathrm{CaO}-\mathrm{MgO}-\mathrm{Al}_{2} \mathrm{O}_{3}-\mathrm{SiO}_{2}-\mathrm{CO}_{2}$ at $6 \mathrm{GPa}$. J. Petrol. 39, 1953-1964.

Eggler D.H., 1978. Stability of dolomite in a hydrous mantle, with implications for the mantle solidus. Geology 6, 397-400.

Foley S.F., Andronikov A.V., 2002. Petrology of ultramafic lamprophyres from the Beaver Lake area of eastern Antarctica and their relation to the breakup of Gondwanaland. Mineral. Petrol. 74, 361-384.

Olafsson M.A., Eggler, D.H., 1983. Phase relations of amphibole, amphibole-carbonate, and phlogopitecarbonate peridotite: petrologic constraints on the asthenosphere. Earth Planet. Sci. Lett. 64, 305-315.

Rock N.M.S., 1991. Lamprophyres. Blackie, Glasgow. pp. 285 .

Ryabchikov I.D., Brey G.P., Bulatov V.K., 1993. Carbonate melts coexisting with mantle peridotites at $50 \mathrm{kbar}$. Petrology 1, 159-163.

Wyllie, P.J., 1978. Mantle fluid compositions buffered in peridotite- $\mathrm{CO}_{2}-\mathrm{H}_{2} \mathrm{O}$ by carbonates, amphibole, and phlogopite. J. Geol. 86, 687-713.

Wyllie P.J., 1987. Volcanic rocks: Boundaries from experimental petrology. Fortschr. Miner. 65, 249-284.

Contact: SF Foley, Institute of Geological Sciences,

University of Greifswald, Jahnstrasse 17a, 17487 Greifswald,

Germany.sfoley@uni-greifswald.de 